\title{
CDISC SDTM Route of Administration Terminology
}

National Cancer Institute

\section{Source}

National Cancer Institute. CDISC SDTM Route of Administration Terminology. NCI

Thesaurus. Code C66729.

Terminology codelist used with Route of Administration within the Clinical Data

Interchange Standards Consortium Study Data Tabulation Model. 